\title{
SZÖRÉNYI IMRE, AZ EGYETLEN SZTÁLIN-DÍJAS MAGYAR TUDÓS ${ }^{1}$
}

\section{IMRE SZÖRÉNYI, THE ONLY HUNGARIAN SCIENTIST WHO WON THE STALIN PRIZE}

\author{
Orosz Ferenc \\ az MTA doktora, tudományos igazgatóhelyettes, Természettudományi Kutatóközpont Enzimológiai Intézet \\ orosz.ferenc@ttk.hu
}

\section{ÖSSZEFOGLALÁS}

Szörényi Imre (1905-1959) jelentős szerepet töltött be a magyar biokémia történetében. Aszszimilálódott zsidó értelmiségi családból származott. A budapesti egyetem orvosi karán Hári Pál tanítványaként kötelezte el magát a biokémiai kutatómunka mellett. Származása miatt diplomája megszerzése után előbb svájci és németországi emigrációba kényszerült - itthon nem számíthatott megfelelő állásra -, majd 1933-tól 1950-ig a Szovjetunióban, Kijevben dolgozott. Ekkor pártkezdeményezésre hazahívták, és megbízták az MTA Biokémiai Intézet megalapításával. Néhány hónap múlva visszalátogatott Kijevbe, ahonnan súlyos betegsége miatt csak 1953ban tért véglegesen haza. 1952-ben megosztott Sztálin-díjat kapott. 1953-tól tudta ténylegesen formálni a Biokémiai Intézet arculatát, amely munkássága nyomán a magyar biokémia egyik meghatározó műhelyévé vált. Korai halála ellenére, tanítványain keresztül is maradandó hatást gyakorolt a magyar biokémiára.

\section{ABSTRACT}

Imre Szörényi (1905-1959) played an important role in the history of Hungarian biochemistry. He was Pál Hári's disciple in the Medical Faculty of the Budapest University, where he bound himself to do biochemical research. He came of an assimilated Jewish intellectual family, and because of his descent he could not expect a suitable job in Hungary, thus he had to emigrate to Switzerland, later Germany then he was working in Kiev, in the Soviet Union, from 1933 till 1950. This year the Hungarian Communist Party called him back home to Hungary and he was entrusted with establishing the Institute of Biochemistry of the Hungarian Academy of Sciences. After a few months, he visited Kiev where became seriously ill, and returned finally to Hungary

1 Rendhagyó biológussorsok a 20. században. Az MTA Tudomány- és Technikatörténeti Bizottság előadóülésén, Budapesten, 2019. szeptember 13-án elhangzott előadás szerkesztett változata. Ezúton mondok köszönetet Dr. Háy Dianának, az MTA Levéltára vezetőjének, Dr. Baráth Magdolnának, az Állambiztonsági Szolgálatok Történeti Levéltára osztályvezetőjének és Prof. Dr. Müller Miklósnak értékes segítségükért. 
only in 1953. He received a shared Stalin Prize in 1952. He was able to effectively form the face of the Institute of Biochemistry from 1953. On the basis of his activity, the institute became one of the determining workshops of Hungarian biochemistry. In spite of his early death, he exerted long-lasting influence on the Hungarian biochemistry through his disciples.

Kulcsszavak: MTA Biokémiai Intézet, Hári Pál, Szörényi Tivadar, emigráció, Szovjetunió, Sztálindíj, Omry Ronen

Keywords: Institute of Biochemistry, Hungarian Academy of Sciences, Pál Hári, Tivadar Szörényi, emigration, Soviet Union, Stalin Prize, Omry Ronen

Mottóként egy 2004-ből származó interjúból idézek, amelyben Szörényi Imre egyik tanítványa, Pusztai Árpád beszél első mesteréröl:

„Bár Szörényi Imre nem tartozott a Szent-Györgyi-generáció biokémikus társaságához, munkássága szervesen beleilleszkedett a nagy hagyományba. A mai életünk egyik furcsasága az, hogy a második világháborút a Szovjetunióban túlélő és Sztálin-díjjal jutalmazott nagy tudósról manapság szinte senki sem beszél, mintha öt szégyellnünk kellene. Mintha valamibe keve-

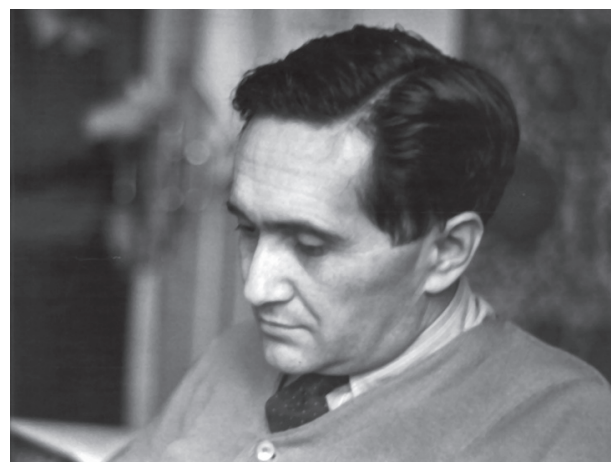

Szörényi Imre (1905-1959), az MTA Biokémiai Intézet alapító igazgatója (A fényképet Gulyás Márta bocsátotta a szerző rendelkezésére) redett volna azzal, hogy a háború utáni kommunista uralom alatt kivételes képességére az MTA hálózatához tartozó Biokémiai Intézetet alapítottak. Ö ezt a privilégiumot az egyetemes tudomány javára hasznosította. És ezt már azért is világosan kellene látnunk, mert ebből az intézetből nőtt ki a manapság méltán világhírü budapesti MTA Enzimológiai Intézete." (Darvas, 2004)

\section{CSALÁDJA}

Szörényi Imre Sztálin-díjas biokémikus akadémikus, az MTA Biokémiai (később Enzimológiai) Intézetének alapító igazgatója középosztálybeli, viszonylag jómódú asszimilálódott zsidó családból származott. Édesapja még Schwartz Tivadarként született, édesanyja Schwitzer Berta volt. Az anyai ágat tudjuk távolabbra visszavezetni; ősei Morvaországból költöztek Északnyugat-Magyarországra, Nyitra és Trencsén megyébe. Édesanyja a Nyitra megyei Vágmedencén született, 
Szörényi Imre is ugyanitt, 1905. május 12-én. (Anyai nagyanyja Kuffler Johanna, akinek a testvére, Kuffler Benjámin volt a nagyapja a neves agykutatónak, Kuffler Vilmosnak, aki így Szörényi Imre másod-unokatestvére.) Apja és apai nagyszülei egyaránt Abaúj vármegyében születtek, de a dédszülök közül csak a dédapa neve ismert, és születési helye neki is ismeretlen. Lehetséges, hogy ö még Galíciában született, s ismeretes, hogy onnan később kezdődött a zsidók betelepülése, mint a nyugati országrészbe történő morvaországi bevándorlás. Schwartz Tivadar szülei tíz gyermekéből kilencedikként született Kassán, 1863. november 11-én. Orvosi praxisát már Szörényi Tivadarként kezdte meg 1890-ben. Előbb különböző fővárosi és vidéki fürdőkben, majd huzamosabban a felvidéki Bártfafürdőn müködött fürdőorvosként, ahol Erzsébet nevü leányuk is született, 1904-ben (Góczán-Mihály, 1989). 1905-ben költözött a család Budapestre, de az év egy részét valószínüleg még ezután is Bártfafürdön töltötte. Szörényi Imre a költözés évében született, édesanyja szülőhelyén. Apja később Budapesten a Liget Szanatóriumban kapott állást (ott, ahol Ady 1919-ben elhunyt) idegorvosként (Góczán-Mihály, 1989), de magánpraxist is folytatott. Idővel egyik vezetője lett az Országos Balneológiai Egyesületnek. A témába vágó szaktanulmányokat és tudománynépszerüsítő cikkeket is írt. 1892-től kezdve szabadkőmüves volt. Előbb a kassai Fórum majd a Resurrexit páholynak, majd az 1909-ben alakult budapesti Kazinczy páholynak volt a tagja. Ez utóbbi munkaprogramjaként a szellemi felvilágosodás terjesztését és a közoktatás fejlesztését jelölte meg, megalapította az Országos Ismeretterjesztő Társaságot, és anyagilag támogatta a Világ és a Darwin című folyóiratokat. Szörényi Tivadar feleségével együtt belépett az 1905-ben létrejött Magyar Teozófiai Társaságba is.

Harmadik gyermekük, István 1907-ben már Budapesten született. Utólagos anyakönyvi bejegyzése szerint szülei - s ezáltal a gyermekek is - 1910-ben áttértek a római katolikus vallásra, meglépve evvel a névmagyarosítás után az asszimiláció újabb szimbolikus lépését. Egy megemlékező cikk szerint (Góczán-Mihály, 1989) még egy gyermekük született, ennek a ténynek azonban nem akadtam nyomára. Szörényi Tivadarnét 1918-ban elvitte a spanyolnáthajárvány. Néhány évvel később, férje monumentális síremléket állított neki, amely mint „teozófus síremlék” ismert. Egykor a Kerepesi úti, ma az Új köztemetőben áll. Az eléggé lepusztult szobron jól kivehető még az önmaga farkába harapó kígyó, a teozófusok jelképe.

E családi háttér mellett nem teljesen váratlan, hogy a legidősebb gyermek, Szörényi Erzsébet lány létére nemcsak érettségizett, hanem egyetemet is végzett földrajz-természetrajz szakon, majd 1928-ban doktorált is a Pázmány Péter Tudományegyetemen földtan, ásvány-kőzettan és őslénytan tárgyakból. Teljes életútjára nincs mód kitérnem; ,a tengeri sünök világhírü paleontológus specialistájaként" - a háború alatti kényszerű kitérő kivételével - a Magyar Állami Földtani Intézetben dolgozott, 1955-ben megszerezve az akadémiai doktori fokozatot is. 1987-ben hunyt el (Góczán-Mihály, 1989). 


\section{TANULMÁNYAI}

Szörényi Imre apja nyomdokaiba lépett. A középiskolát a VII. kerületi Barcsay utcai Főgimnáziumban végezte, amely érettségije évében vette fel Madách Imre nevét. Az 1919/20-as tanévet, öccsével együtt Pozsonyban, az evangélikus líceumban végezte. Ennek oka nem ismert; talán édesanyjuk halála is közrejátszott ebben. 1922-ben jelesen érettségizett, az iskola értesítője szerint „görögből is tett vizsgálatot”. Ezután beiratkozott a Pázmány Péter Tudományegyetem orvosi karára. Már egyetemi hallgatóként a Hári Pál irányítása alatt müködő élet- és kórvegytani intézetben dolgozott, 1926-tól mint díjtalan gyakornok. 1928-1929-ben a III. számú belgyógyászati klinika externista szakorvosa volt. 1929. január 26-án avatták orvossá.

Hári Pállal való találkozása meghatározónak bizonyult pályafutására nézve. Hári volt hazánkban a biokémiai kutatások egyik megteremtője, nemzetközileg ismert és elismert kutató. Még a Monarchia idejében nevezték ki nyilvános rendes egyetemi tanárnak. Szakmailag és emberileg is nagy hatással volt tanítványaira. Ahogyan egyikük, Székács István fogalmazta: „Rendkívül érdekes ember, jó dzsentri zsidó volt, a budai Goldbergerek unokaöccse. Még ma is ő az én példaképem.” (Hadas, 1995) „Ha tehát Hári Pál viszonyát munkatársaihoz röviden akarom jellemezni, azt kell mondanom, egyrészt példaképül szolgált, másrészt kézen fogva vezette be a fiatal kutatót a tudományos munka elemeitől kezdve a nemzetközi tudományos közösségbe.” (Székács, 1983)

Ezt annál is inkább megtehette, mert Hári az akkor legfontosabb, legtekintélyesebb biokémiai folyóirat, a Biochemische Zeitschrift szerkesztőbizottságának a tagja volt. Itt jelent meg Szörényi első tudományos publikációja, 1927-ben (Szörényi, 1927). Hári példamutató gyakorlata szerint csak Szörényi neve szerepel szerzőként, s csak a közlemény utolsó mondata jelzi, hogy a munka Hári irányításával folyt.

\section{EMIGRÁCIÓBAN}

Diplomájának kézhezvétele után külföldön folytatta pályafutását. Érdemes megemlíteni, hogy valamennyi későbbi fönöke szintén tagja volt a Biochemische Zeitschrift szerkesztőbizottságának. Elöször Baselben, Verzár Frigyes laboratóriumában vizsgálta a tápanyag-felszívódás, különösen a lipidek emészthetőségének biokémiai hátterét. Ezután Berlinbe ment, Julius Wohlgemuth munkatársának, akinél fö témája a fény sejtélettani hatásainak mikroorganizmusokon való vizsgálata volt. Legjelentősebb eredményeit a Berlini Rákkutató Intézetben, Ferdinand Blumenthal laborjában érte el; Arthur Lasnitzkivel két cikket is közöltek a Biochemical Journalben a kationoknak az élesztő erjedési folyamataira, metabolizmusára gyakorolt hatásáról. A cikkek közlésekor már egyikük sem volt Ber- 
linben, mivel Hitler hatalomra jutásakor távozniuk kellett. Blumenthal Csehszlovákiába, Lasnitzki Angliába ment, míg Szörényi visszatért Verzárhoz Svájcba. Itt érte Alekszandr V. Palladinnak, az Ukrán Tudományos Akadémia Biokémiai Intézete igazgatójának - az Ukrán Tudományos Akadémia későbbi elnökének - a hívása, s Kijevbe költözött, ahol 1950-ig maradt. Itt témát váltott, és az izomszövetek anyagcseréjének kérdéseivel, az izomképzés élettani folyamatainak biokémiai hátterével foglalkozott. Első cikke már 1934-ben megjelent az Ukrainian Biochemical Journalben (Українский Біохемічний Журнал), nagyjából egyszerre az előbb említett Biochemical Journalbeli cikkekkel.

Úgy tünik, hogy szovjetunióbeli tartózkodása első éveiben még kapcsolatban maradt Magyarországgal. Ennek meglepő bizonyítéka a Búvár 1936. januári számában közölt cikke (Szörényi, 1936), amelyet 1935 decemberében írt, mivel az 1935-ös Nobel-díj átadást úgy említi, mint ami a napokban történt. A folyóirat Szörényi egykorú fényképét is közli. 1938 márciusában azonban már a Magyar Királyi Belügyminisztérium közleményt ad ki, amelyben kilátásba helyezi magyar állampolgárságának elvesztését, ha továbbra is szovjet „állami szolgálatban” marad. Nővérét egy névtelen feljelentés alapján 1939-ben azonnali hatállyal elbocsátották a Magyar Királyi Földtani Intézetböl, mivel öccse szovjet állampolgár volt (Góczán- Mihály, 1989).

Eközben Szörényi Imre megnősült. A harkovi Kémiai és Gyógyszerészeti Intézetben végzett munkatársát, Broniszlava Cipiszt vette feleségül, aki odesszai zsidó eredetủ családból származott. Fiúk, az ifjabb Imre is ott született, 1937. július 12-én (Ruhel, é. n.). Ez éppen a sztálini terror tetőzésének idejére (1936. szeptember - 1938. augusztus) esett. Csak közvetett adatunk van arra vonatkozóan, hogy mint nyugati gyanús elem, Szörényi élete is veszélyben foroghatott. Két hónapig, télvíz idején Kijev közelében egy nádkunyhóban bujkált, ahová felesége naponta hordta ki az élelmet. ${ }^{2}$ Ez 1938 telén történhetett, de azt nehéz eldönteni, hogy vajon 37-38 vagy 38-39 fordulóján. 1938-ban csak egy, az előző év októberében beküldött cikke jelent meg, míg legközelebb csak 1940-ben publikált. Ugyanakkor egyik, már a háború után megjelent publikációjában 1939. februári kísérlet adatait közli.

A Szörényi családot Kijevből 1941 júliusában az Ukrán Tudományos Akadémia vonatával evakuálták. 1941-től 1943 augusztusáig a család a baskíriai Ufa közelében élt (Ruhel, é. n.). A családfö a Biokémiai Intézetbeli fóállása mellett konzultánsként dolgozott egy pszichiátriai kórházban. Egy itteni munkát örökít meg az egyetlen, a világháború alatt megjelent cikke (Palladin et al., é. n.). 1943 augusztusától 1944 közepéig Moszkvában éltek, majd az Ukrán Tudományos Akadémia vonatával visszatértek Kijevbe (Ruhel, é. n.). Nem meglepő módon

\footnotetext{
${ }^{2}$ Nuridsány Zoltánné, az MTA Biokémiai (Enzimológiai) Intézete egykori munkatársának közlése, Szörényi özvegyére hivatkozva.
} 
Szörényi publikációs listáján 1941-től egy ötéves szünetet találunk, a fentebb említett kivételtől eltekintve. A Szovjetunióban elért eredményeiről, amelyek mindvégig az izomműködés biokémiájával kapcsolatosak, kivétel nélkül orosz és ukrán nyelven, szovjet lapokban számolt be. A cikkek többnyire német vagy angol nyelvü, viszonylag bő összefoglalókat is tartalmaznak. Affiliációként az Ukrán Tudományos Akadémia Biokémiai Intézete van feltüntetve, melynek Szövetfehérje Kutató Osztályát vezette. Ugyanakkor ezen Akadémia Mikrobiológiai Intézete Biokémiai Osztályának is vezetöje volt, ez azonban nincs feltüntetve a cikkeken. Itt antibiotikum-kutatással foglakozott, amire később még kitérek.

\section{HAZATÉRÉS}

Szörényi hazahívása 1949-ben merült fel; a kérdéssel a legmagasabb szintű politikai vezetés foglalkozott. A Magyar Dolgozók Pártja Központi Vezetősége Titkársága 1949. június 8-i és október 19-i ülésein tárgyalt Szörényi hazahívásáról, melyet a Magyar Tudományos Tanács Pártkollégiuma is támogatott. A Pártkollégium elé került előterjesztés szerint felmerült a neve mint szegedi vagy debreceni tanszékvezető, illetve a Tihanyi Biológiai Intézet igazgatója; ezek a posztok ugyanis betöltetlenek voltak. Ugyanitt olvasható, hogy Szörényi is hajlott rá, hogy hazatérjen, hiszen Budapesten élt apja és nővére is; valamint az is, hogy Szörényi nem tagja a pártnak (Magyar Tudományos Tanács iratai 4/3). Végül is, „kérésünkre a Szovjetunió átengedte nekünk Szörényit”3, aki 1950. január 25-én családjával együtt Budapestre érkezett. ${ }^{4}$

Márciusban körvonalazódott, hogy a legjobb megoldás az lesz, ha egy új intézetet hoznak létre a számára, az MTA Biokémiai Intézetét; ez beleillett az akkori trendbe, az MTA intézethálózatának kialakításába. 1950. március 29-én az MDP KV Titkársága is áldását adta a tervre, és 1950. május 3-án a 129/1950. számú minisztertanácsi rendelet kimondta az intézet június 1-jével való megalakítását (Elnöki iratok 60/2/15). Ugyanevvel a dátummal egy Vallás- és Közoktatásügyi Minisztériumi (VKM) rendelet (VKM 1404-Sz322-1/1950.VI/1.) pedig megbízta a Pázmány Péter Tudományegyetem Orvosi Kara Biokémiai Tanszékének vezetésével. Gondot jelentett az intézet helyének kiválasztása, addig is, amíg a soron következö ötéves tervben felépül majd egy új épület. Az Országos Közegészségügyi Intézet Gyáli úti épületére esett a választás, ahol az intézet 1957-ig müködött.

\footnotetext{
${ }^{3}$ Alexits György levele a Rákosi-titkárság számára, 1950. március 6. (Országos Levéltár M-KS 276 f. 65 cs. 328 ö. e. 577 .).

${ }^{4}$ Erdős Tamás levele a Rákosi-titkárság számára, 1950. március 3. (Országos Levéltár M-KS 276 f. 65 cs. 328 ö. e. 548.).
} 


\section{VISSZA A SZOVJETUNIÓBA}

Szörényit az MTA közgyülése 1950. december 2-án levelező taggá választotta, az Orvosi Tudományok Osztályára. Azonban maga Szörényi ekkor már ismét Kijevben volt, családjával együtt, ahová egy konferenciára utazott. (Az MTA közgyülésre szánt előadását is felolvasták helyette.) A visszatérés előtt, december végén infarktust kapott, amiről felesége táviratban értesítette az MTA elnökét, Rusznyák Istvánt 1951. január 3-án (Elnöki iratok 62/1/2). Felépülése igen nehezen haladt, 1952 tavaszára került olyan állapotba, hogy gondolhatott a hazatérésre. Ekkorra azonban lejárt a szovjet útlevele, és nem tudott visszajönni. Erröl 1952. március 28-i, Rusznyák Istvánhoz küldött távirata tanúskodik, amelyböl kiderül, hogy a párt Központi Bizottságának újra ki kell őt kérnie a Szovjetuniótól (Elnöki iratok 64/3/22). Az ügyintézés azonban igen nehezen haladt, így Rákosihoz fordult levélben ${ }^{5}$, hogy sürgesse meg az ügyet. Végül csak 1953 januárjában, több mint kétévi távollét után tudott visszatérni Magyarországra.

Szovjetunióbeli tartózkodása során azonban történt egy unikális esemény: 1952. március 20-án első magyarként és egyetlen magyar tudósként megosztott Sztálin-díjat kapott, „,egy új gyógyszerkészítmény (Mikrocid) kidolgozásáért és az orvosi gyakorlatba való bevezetéséért" (Elnöki iratok 64/3/22).

\section{ÚJRA ITTHON}

Ismételt hazatérése után nagy reverenciával fogadták, megválasztották az MTA rendes tagjának, és meg kellett nyilatkoznia ideológiai kérdésekben is. Az Akadémia 1953-as nagygyülésén korreferátumot tartott $A$ biológia néhány törvénye és azok megismerésének módjai és feltételei Sztálin „A szocializmus közgazdasági problémái a Szovjetunióban" címü müvének megvilágitásában címmel, ahol kitért Ivan V. Micsurin és Trofim Gy. Liszenko munkásságára is (Szörényi, 1953). Elnöke lett az MTA Élőfehérjekutatási Szekciójának, amelyet az obskúrus lepesinszkajai elmélet igazolására hoztak létre (Müller, 2013). A hozzászólásból és a bizottsági jegyzőkönyvekből is úgy tűnik, hogy Szörényi bár eleget tett az elvárásoknak, némi távolságtartással tekintett az áltudományos nézetekre, és igyekezett a valós biológiai problémákra irányítani a figyelmet. A saját intézetéből kikerült „élőanyagos” cikkekben sem szerepel szerzőként. Érdemes megjegyezni, hogy egy 2004-es visszaemlékezés azok közé sorolja, akik „érvényesítették nem elhanyagolható befolyásukat, nemegyszer önmaguk veszélyeztetésével”, hogy megvédjék a támadásoktól azokat a genetikusokat, akik valódi tudományos mun-

\footnotetext{
${ }^{5}$ Szörényi Imre levele Rákosi Mátyásnak, Kijev, 1952. szeptember 7. (Országos Levéltár M-KS 276 f. 65 cs. 328 ö. e.).
} 
kát végeztek (Igali, 2002). Gyenge egészségi állapota miatt is tehertételnek érezte ezeket a feladatokat, és számtalan egyéb funkcióját, s ezekről 1955. február 24-én lemondott, hogy az intézeti munkára koncentrálhasson (Elnöki iratok 73/4/31). (Az egyetemi tanszék vezetését már 1953-ban átengedte.)

Erre nagy szükség is volt, mivel több mint kétéves távolléte alatt az intézetben zavaros viszonyok uralkodtak. A magukra maradt pályakezdő fiatalok nehezen birkóztak meg feladatukkal, és személyi ellentétek is hátráltatták a munkát (Elnöki iratok 62/5/41). Szörényi azonban újra kézbe vette az irányítást és ,, a fehérjék kémiai szerkezete és specifikus biológiai funkciója közötti kapcsolat” tanulmányozását tűzte ki mindenki feladatául (Intézeti beszámoló, 1959). Építve korábbi munkásságára, az izomból és élesztőből kinyerhető glikolitikus enzimeket, köztük a glicerinaldehid-3-foszfát dehidrogenázt jelölte ki a vizsgálatok tárgyául. Ez szerencsés választás volt, mert ezek az enzimek nagy mennyiségben és könnyen voltak tisztíthatók, s így a kor színvonalán lehetett szerkezet-funkció vizsgálatokat végezni rajtuk. (Lásd részletesebben erről és az MTA Biokémiai Intézet 50-es évekbeli történetéről: Orosz, 2010 és az ott közölt hivatkozások.) A Comparative Studies on D-glyceraldehyde-3-phosphate Dehydrogenase sorozat darabjait 24-ig számozták, még Szörényi 1959-es halálán túl is. A téma évtizedekre megszabta az intézet tevékenységét.

Az intézet magja 1956 után is együtt maradt, s a beindult munkát a következő évben történt költözködés is csak rövid időre akasztotta meg. A költözés terve már Szörényi második hazatérésekor felmerült, ki is jelöltek erre a célra a Gorkij fasor 40-ben egy épületet, akkor azonban anyagiak hiányában a költözés meghiúsult (Elnöki iratok 71/3/125). Szörényi elkeseredetten küzdött a méltó munkafeltételek megteremtéséért, amint erről a különböző szakmai és politikai hivatalosságokkal való levelezése tanúskodik. Végül az intézet csak 1957-ben került a Karolina útra, a Honvédség Egészségügyi Tudományos Kutató Intézetének helyére (Intézeti beszámoló, 1957). Az intézeti legendárium szerint a hely kiválasztásában szerepe volt annak, hogy Szörényi a szomszédos Ábel Jenő utcában lakott, s eluralkodó betegsége mellett is képes volt a néhány perces sétát az intézetig megtenni.

1956 után az intézet s maga Szörényi is bekapcsolódott a biokémiai kutatások nemzetközi vérkeringésébe. Addig a publikációk - néhány cirill betűs cikket kivéve - föként az Acta Physiologica Hungaricában jelentek meg. (A „nyugati" lapokban való közlésnek valószínűleg nem csak szakmai akadályai lehettek.) 1957-től kezdve azután megváltozott a helyzet, mégpedig rögtön tanítványai $\mathrm{Na}$ ture-beli cikkeivel. Halála előtt néhány hónappal, 1958 szeptemberében még az is megadatott számára, hogy helyettesével, Szabolcsi Gertruddal együtt előadást tarthatott Bécsben, az International Union of Biochemistry 4. kongresszusán (Intézeti beszámoló, 1958). Majd decemberben beküldött egy cikket a Biochimica Biophysica Actába, ami már posztumusz jelent meg. Utoljára pontosan negyedszázaddal elötte publikált „nem szocialista” lapban, a Biochemical Journalben. 
1959. január 17-én vitte el a szíve; vélhetően az intézetben, mivel a haláleset bejelentője egyik munkatársa volt. ${ }^{6}$ Az intézet dolgozói kezdeményezték, hogy a Biokémiai Intézet vegye fel elhunyt igazgatója nevét (Elnöki iratok 36/R számon iktatva), ami azonban nem járt sikerrel. Tanítványain keresztül Szörényi Imre maradandó hatást gyakorolt a magyar biokémiára. Kevesebb, mint kilenc évig volt az MTA Biokémiai Intézetének igazgatója, ténylegesen alig hat évig végezte az irányítást. Azonban ez a néhány év nemcsak ahhoz volt elegendő, hogy „pályára állítsa” az intézetet, de további évtizedekre alapvetően megszabta az egységes kutatási irányt és a munkastílust.

Szörényi Imre sírja a Fiumei úti sírkert müvészparcellájában található, Medgyessy Ferenc és Weiner Leó sírja között, ahol azonban rajta kívül is van néhány tudósnak sírhelye (például: Semmelweis Ignác, Fejér Lipót és Riesz Frigyes).

\section{EPILÓGUS}

Az 1962-ben alakult Magyar Biokémiai Társaság döntése értelmében Szörényi halálának 10. évfordulóján róla nevezték el a harmincöt évnél fiatalabb, eredményes munkát végző kutatók számára adható elismerést, míg mesteréről, Hári Pálról a hazai biokémiai kutatás és oktatás területén elért jelentős eredmények elismerésére szolgáló emlékplakettet (Elődi, 1970). Ma már egyik dij sem létezik; nem az én tisztem az okokat keresni.

Szörényi halála után felesége továbbra is az MTA Biokémiai Intézetében dolgozott, majd egy évet Massachusettsben, a Brandeis Egyetemen volt vendégkutató. A házaspár egyetlen gyermeke, ifj. Szörényi Imre ekkoriban a szomszédos Harvardon dolgozott PhD értekezésén. Ifj. Szörényi 1956-ban hagyta el Magyarországot, Izraelbe ment, nevet változtatott, és a Jeruzsálemi Egyetemen szerzett szlavisztikából diplomát (Ruhel, é. n.). A PhD után egy időre visszatért az alma materba, majd 2012-ben bekövetkezett haláláig a michigani Ann Arborban volt a szlavisztika professzora. Kétszer nősült, mindkét házasságából egy-egy fiú és leánygyermek született; több unokája is van. Szörényi Imre így utódaiban is tovább él, még ha neve nem is öröklödik tovább.

\section{IRODALOM}

Darvas B. (2004): Távfutás (Öttusa Pusztai Árpáddal, I. rész) http://www.bdarvas.hu/portre/ idn 3504

Elődi P. (1970): A Magyar Biokémiai Társaság IV. nagygyűlésének néhány tanulsága. Magyar Tudomány, 77, 2, 124-125.

\footnotetext{
${ }^{6}$ A bejelentő Elődi Pál volt (URL1).
} 
Góczán F. - Mihály S. (1989): Emlékezés Dr. Szörényi Erzsébetre. Földtani Közlöny, 119, 1, 1-4. https://epa.oszk.hu/01600/01635/00262/pdf/EPA01635_foldtani_kozlony_1989_119_1_01-04. pdf

Hadas M. (1995): Beszélgetés Dr. Székács Istvánnal. Replika, 19-20, 11-41. http://www.replika. hu/system/files/archivum/replika_19-20_02_beszelgetes_szekacs_istvannal.pdf

Igali S. (2002): A liszenkoizmus Magyarországon. Ideológiai-politikai diktatúra a XX. század természettudományában. Valóság, 45, 3, 39-59.

Intézeti beszámoló - MTA Biokémiai Intézete tudományos beszámoló (1957, 1958, 1959)

MTA Levéltára: Elnöki iratok; Magyar Tudományos Tanács iratai

Müller M. (2013): A Kossuth Prize in 1952 - The Short Term Rule of Dialectic Soviet Cell Biology in Hungary. Communicationes de historia artis medicinae, 222-225, 43-58.

Orosz F. (2010): Az MTA Enzimológiai Intézetének első évtizede. Magyar Tudomány, 171, 12, $1486-1491$.

Palladin, A. V. - Szörényi I. T. - Наjkina В. І. (Палладин А. В. - Сорени Д./!/ Т. - Хайкина Б. И.) (é. n.): «О некаторых особенностях обмена вешеств при эпилепсии.» $[\mathrm{Az}$ anyagcsere néhány jellemzőjéről epilepsziában.] Бюллетень экспериментальной биологии и медицины, 15?, 1-2, 31-34.

Ruhel, F. (Рюхель, Ф.) (е́. n.): РОНЕН, Омри [Ronen, Omry]. http://www.ruthenia.ru/moskva/ encycl/r/ronen.htm

Székács I. (1983): Hári Pál emléke (1869-1933). Orvosi Hetilap, 124, 7, 259-262.

Szörényi E[merich] (1927): Deutung and Folgen der Veränderung in der Körperzusammensetzung kleiner, an Hunger oder Unternährung verendeter Tiere. Biochemische Zeitschrift, 183, 4-6, 350-361.

Szörényi I. (1936): Mi váltja ki és mi irányítja az élölények növekedését? Búvár, 2, 1, 47-50.

Szörényi I. (1953): A biológia néhány törvénye és azok megismerésének módjai és feltételei Sztálin „A szocializmus közgazdasági problémái a Szovjetunióban” címü művének megvilágításában. Az MTA Társadalom-Történeti Osztályának Közleményei, 3, 3-4, 310-315.

URL1: https://www.familysearch.org/ark:/61903/3:1:S3HT-D4M7-WMT 